\title{
INDIVIDUAL ANALYSIS OF CREATINE KINASE CONCENTRATION IN BRAZILIAN ELITE SOCCER PLAYERS
}

\author{
ANÁLISE INDIVIDUAL DAS CONCENTRAÇÕES DA CREATINA QUINASE EM JOGADORES \\ DE ELITE DO FUTEBOL BRASILEIRO
}

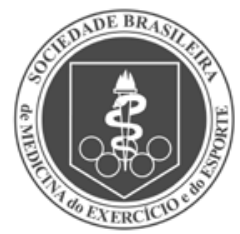

Artigo Original

ORIGINAL ARTICLE

ARticulo Original

\section{ANÁLISIS INDIVIDUAL DE CONCENTRACIONES DE LA CREATINA QUINASA EN FUTBOLISTAS BRASILEÑOS DE ELITE}

\begin{abstract}
Adriano Lima Alves ${ }^{1}$ (Profissional de Educação Física) Emerson Silami Garcia² (Profissional de Educação Física) Rodrigo Figueiredo Morandi ${ }^{1}$ (Profissional de Educação Física) João Gustavo Claudino 3 (Profissional de Educação Física) Eduardo Mendonça Pimenta ${ }^{4}$ (Profissional de Educação Física) Danusa Dias Soares ${ }^{1}$ (Profissional de Educação Física)

1.Universidade Federal de Minas Gerais, Belo Horizonte, MG, Brasil. 2. Universidade Federal do Maranhão (UFMA), Departamento de Educação Física São Luís, Maranhão, Brasil.

3. Universidade de São Paulo, São Paulo, SP, Brasil.

4. Universidade de Leon, Spain.
\end{abstract}

\section{Correspondencia:}

Rua: Colomita, 120. Bairro Santa Teresinha, Belo Horizonte, MG, Brasil. adrianolimaa@gmail.com

\begin{abstract}
Objective: to determine the individual profile of blood concentration of creatine kinase (CK) in elite soccer players as well as to analyze the CK concentrations in different periods during the Professional Brazilian Championship. Methods: resting CK of 17 soccer players was evaluated before the competition (pre-season) and after the matches (36 and 46 hours after the games) ( $\left.\mathrm{CK}_{\text {Game }}\right)$ for the individual blood $\mathrm{CK}$. The Chi-square test was used to analyze the individual CK during the season. The competitive season was divided into three periods: initial, intermediate and final. The one-way ANOVA with repeated measurements followed by post hoc Student-Newman-Keuls test was used to compare the individual CK of each soccer player in each competitive period. The significance level was set at $p<0.05$. Results: the highest frequency of individual CK was found in the second quartile (71 observations) and the lowest frequency in the first (26 observations) and the fourth quartile (40 observations) compared to the expected number of 45.8 $\left(x^{2}=22.21\right)$. CK concentrations were lower in the intermediate (mean=66.99\%) and final (mean=60.21\%) periods than in the initial period (mean=89.33\%). Conclusion: soccer players did not show elevated muscle damage and probably a muscle adaptation occurred in the competition, due to the reduction of CK concentrations observed.
\end{abstract}

Keywords: soccer, muscle strength, creatine/blood.

\section{RESUMO}

Objetivo: determinar o perfil individual das concentrações sanguíneas de creatina quinase em jogadores de futebol de elite, bem como, analisar as concentrações de CK em diferentes períodos durante o campeonato brasileiro. Métodos: a CK de repouso de 17 jogadores de futebol foi avaliada antes da competição (pré-temporada) e após as partidas (36 e 46 horas após os jogos) ( $C K_{\text {Game }}$ ) para obter a CK sanguínea individual. O teste de Chi-quadrado foi utilizado para analisar a CK individual durante a temporada. A temporada competitiva foi dividida em três períodos: inicial, intermediário e final. A ANOVA one-way com medidas repetidas seguida pelo teste post hoc Student-Newman-Keuls foi utilizada para comparar a CK individual de cada jogador de futebol em cada período competitivo. O nível de significância adotado foi de $p<0,05$. Resultados: a maior frequência da CK individual foi encontrada no segundo quartil (71 observações) e a menor frequência no primeiro (26 observações) e no quarto quartil (40 observações) em comparação com o número esperado de 45,8 $\left(x^{2}=22,21\right)$. As concentrações de CK foram menores nos períodos intermediário (média $\left.=66,99 \%\right)$ e final ( média $=60,21 \%$ ) do que no período inicial (média $=89,33 \%$ ). Conclusão: os jogadores de futebol não apresentaram dano muscular elevado e provavelmente uma adaptação muscular ocorreu na competição, devido à redução observada das concentrações de CK.

Palavras-chave: futebol, força muscular, creatina/sangue.

\section{RESUMEN}

Objetivo: determinar el perfil individual de las concentraciones sanguíneas de creatina quinasa en futbolistas de elite, y evaluar las concentraciones de CK en diferentes períodos durante el campeonato brasileño. Métodos: la CK de reposo de 17 futbolistas se evaluó antes de la competición (pretemporada) y después de los partidos (36 y 46 horas después de los juegos) (CK Game) para obtener la CK sanguínea individual. La prueba de Chi-cuadrado se utilizó para analizar la CK individual durante la temporada. La temporada competitiva se dividió en tres periodos: inicial, intermedio y final. El ANOVA one-way con medidas repetidas seguido por el test post hoc Student-Newman-Keuls se utilizó para comparar la CK individual de cada futbolista en cada período competitivo. El nivel de significación se fijó en $p<0,05$. Resultados: la mayor frecuencia de la CK individual fue encontrada en el segundo cuartil (71 observaciones) y la frecuencia más baja en el primero (26 observaciones) y el cuarto cuartil (40 observaciones) en comparación con el número esperado de 45,8 ( $\left.x^{2}=22,21\right)$. Las concentraciones de CK fueron menores en los períodos intermedio (media $=66,99 \%$ ) y final (media $=60,21 \%$ ) que 
en el período inicial (media = 89,33\%). Conclusión: las futbolistas no presentaron un daño muscular alto y probablemente una adaptación muscular ocurrió en la competición, debido a la reducción observada de las concentraciones de CK.

Palabras clave: fútbol, fuerza muscular, creatina/sangre.

\section{INTRODUCTION}

The main Brazilian Soccer Championship has been played with a variation of one game or two per week for seven months. The interval between games may not be enough for an adequate recovery and that can expose the soccer players to an elevated muscle damage ${ }^{1-3}$. Moreover, soccer is an intermittent and high intensity sport ${ }^{4}$ presenting many eccentric muscle actions as jumps and direction changes during a match ${ }^{5}$. Thus, muscle actions are the main causes of skeletal muscle damage ${ }^{6}$ which increase the permeability of the plasmatic membrane and the release of cytoplasmatic enzymes into the blood stream ${ }^{7}$. Among these enymes, creatine kinase (CK) has been described as a good marker of muscle damage and the peak CK concentration has been associated with changes in the peak of maximal isometric strength as well as the changes in the knee-joint range of motion ${ }^{8}$.

Although CK concentration during a soccer competition has been investigated ${ }^{9,10}$ and the results have contributed to enabling the adjustment of the training load, it lowered the unbalance between stress and muscle recovery and the injury risk ${ }^{11}$. These studies are contradictory. While some studies reported no changes in CK concentration ${ }^{9,12}$ others showed CK concentration decreases during a competition ${ }^{10}$. In addition, the absolute values of CK concentration have been used in some of the previous studies which evaluated CK concentration of soccer players ${ }^{1,9,10,13,14}$.

In sports, the use of fixed reference values for CK concentration has been proposed for monitoring training load, these fixed reference values indicate a threefold for injury risk augmented ${ }^{13,15}$. The reference value of physiological parameters are important for interpretation of data ${ }^{16}$. However, the use of fixed reference values for CK concentration as indicators of severe muscle damage is made difficult due to rather high inter and intra individual variability ${ }^{6,7,15}$. Another concurring factor might be the training status of the athletes ${ }^{17}$. Therefore, the use of a fixed reference value may underestimate or overestimate the presence of muscle damage. Moreover, recently, a joint consensus statement about monitoring training status of athletes suggested the definition of a range of meaningful differences by determination of individual ranges to the markers utilized ${ }^{18}$.

We have not found studies describing the CK concentration profile of elite soccer players during a competitive season based on individual values. Therefore, the main purposes of the present investigation were a) to determine the individual's profile of blood CK concentration of elite soccer players and b) to analyze the CK concentration in different periods during a Professional Brazilian First Division Championship.

\section{METHODS}

seventeen players from a first-division Brazilian soccer team volunteered for the study. At the beginning of the season, the age and body mass of the soccer players were registered, $26.6 \pm 3.7$ years and $77.8 \pm 5.6$ $\mathrm{kg}$, respectively. At baseline, body mass was measured using standardized procedures, with a calibrated scale (Filizola, Brazil), their percent of body fat was estimated by using the Jackson and Pollock ${ }^{19}$ equation (i.e. sum of chest, axilla, triceps, subscapular, abdomen, suprailium, and thigh skin folds). The $\mathrm{VO}_{2 \max }$ was estimate by specific soccer test, Yoyo Endurance Test level $2^{4}$, with the players using their soccer shoes in the field ${ }^{4}$. This test was performed at the beginning of the season.
This study had the approval of the Ethics Committee of the Minas Gerais Federal University, Brazil (Protocol 485/10) and all volunteers signed an informed consent form prior to participation in the study.

\section{Procedures}

Blood CK concentration was assessed by reflectance photometry at $37^{\circ} \mathrm{C}$ (Reflotron Plus; Roche, Germany), previously calibrated. After the finger asepsis by using alcohol, a 30- $\mu$ l blood sample was drawn out into a heparinized capillary tube and it was later put on specific reagent strips which were inserted into the instrument. The CK concentration baseline values ( $\mathrm{CK}_{\mathrm{Bas}}$ ) and the maximal concentration of $\mathrm{CK}$ were employed to determine the individual's profile of blood CK concentration of elite soccer players. The $\mathrm{CK}_{\text {Bas }}$ were obtained during the soccer players' presentation after a 30-day rest from any physical activity.

During the competitive season, CK concentration was evaluated between 36 and 46 hours post games ( $\mathrm{CK}_{\text {Game }}$ ), a period in which the peak of CK concentration is most likely reached ${ }^{1,20}$. The maximal concentration of $\mathrm{CK}_{\text {Game }}$ found throughout the season, was denominated as $\mathrm{CK}_{\mathrm{Max}}$. In the period encompassing the end of the game and the evaluation of $\mathrm{CK}_{\mathrm{Game}}$ the soccer players simply rested or performed activities considered to be light.

The maximal difference of blood concentration of $C K\left(\Delta C K_{M a x}\right)$ was calculated by using the following equation 1 :

$\Delta \mathrm{CK}_{\text {Max }}=\mathrm{CK}_{\text {Max }}-\mathrm{CK}_{\text {Bas }}$

Therefore, the $\Delta \mathrm{CK}_{\operatorname{Max}}$ was considered to be $100 \%$ and this value was employed to relativize the difference between the $\mathrm{CK}_{\text {Game }}$ and $\mathrm{CK}_{\text {Bas }}$. The percentage relation between $\Delta C K_{\text {Game }}$ and $\Delta C K_{\text {Max }}$ was denominated as $\% \triangle \mathrm{CK}_{\text {Game }}$ (Equation 2):

$\% \Delta C K_{\text {Game }}=\Delta C K_{\text {Game }} / \Delta C K_{\text {Max }} \times 100$

The $\% \Delta \mathrm{CK}_{\text {Game }}$ was thus grouped into quartiles (i.e., $1^{\text {st }}, 2^{\text {nd }}, 3^{\text {rd }}, 4^{\text {th }}$ ): $\leq 25 \%,>25$ and $\leq 50 \%,>50$ and $\leq 75 \%$, more than $>75 \%$, respectively. This recording procedure of CK was similar to that of Yamin et al. ${ }^{21}$. The $\mathrm{CK}_{\text {Game }}$ measurements were included only if the soccer players played more than 75 minutes per game ${ }^{2}$, did not sustain any muscle strain injury and had not taken any kind of medicine. The occurrence of muscle injury was confirmed by the magnetic resonance imaging (MRI) (Magnetom Vision Plus 1.5 Tesla., Siemens, Germany). Moreover, to be included in the study, the soccer players should have had at least four CK concentration evaluations throughout the season.

The blood CK concentrations of the players were evaluated after each of the 25 official games of the 2010 Brazilian championship from July to December. The CK concentration response during the competition was shown in accordance with the division of the competitive calendar in three periods (i.e., initial, intermediate and final). That division was done in accordance with the number of evaluated games, thus each period would have a similar number of evaluations. The initial period was arranged by grouping the first nine analyses of the games which took place between July and August. The intermediate period corresponded to the month of September when the $10^{\text {th }}$ to the 
17th games were evaluated. At the final period, eight games that took place between October and November were analyzed. For this analysis, a higher CK concentration was used for each soccer player from each period. Beyond the inclusion criterion above, for this analysis, there was an inclusion criterion that the soccer players should have at least one CK concentration evaluation in each period and not have remained more than 20 consecutive days without any training at all, which is considered to cause detraining in soccer players $^{22}$.

\section{Monitoring training load}

In the training sessions, the workload was recorded by counting the minutes of effective training for each soccer player, to determine the training volume (i.e. minutes trained in each period) and by the training intensity defined as the heart-rate percentage (i.e. \%HR ${ }_{\text {Max }}$ ) (Polar Team System ${ }^{\circledR}$; Polar, Finland). The highest heart-rate value reached by the soccer players during training sessions or friendly games was used as their maximal heart rate $\left(\mathrm{HR}_{\mathrm{Max}}\right)^{23}$. The training volume was recorded during games and training sessions. However, the intensity training was recorded only in the training sessions, since according to soccer rules, it is not allowed to use the heart rate monitors in official games. The environmental conditions during the season was recorded according to data supplied by the National Institute of Metereology.

\section{Statistical analysis}

The normality of data was analyzed using the Kolmogorov-Smirnov test. The data that have not shown normality were presented as median and amplitude between the minimal and maximal values and the ones that presented normality were expressed as mean and standard deviation. For the analysis of the individual's profile of blood CK concentration of the $\% \Delta \mathrm{CK}_{\mathrm{Game}}$ frequency in each quartile during the competition, the chi-square $\left(X^{2}\right)$ was employed, the chi-square test had as a null hypothesis that every quartile was equal. The comparison among the three periods of the competitive calendar was used through ANOVA one way with repeated measurements followed by the Student Newman Keuls test, in which the highest measurement of $\% \Delta \mathrm{CK}_{\text {Game }}$ for each soccer player in each period was used. To verify whether $\mathrm{CK}_{\text {Game }}$ was different from $\mathrm{CK}_{\text {Bas' }}$ the paired $t$-test was used; in which the lowest value of $\mathrm{CK}_{\text {Game }}$ of the season was considered. The Sperman correlation coefficient was performed to verify the relationship between changes in training volume, training intensity and CK during the season. The adopted significance level was $p<0.05$. The data were analyzed using the sigma Stat 3.5 pack. The descriptive analysis of data was expressed in terms of mean, standard deviation, median and frequency distribution.

\section{RESULTS}

The percent of body fat (\%fat) and $\mathrm{VO}_{2 \max }$ of the soccer players were $9.5 \pm 1.4 \%$ and $55.5 \pm 3.6 \mathrm{~mL} \cdot \mathrm{kg}^{-1} \cdot \mathrm{min}^{-1}$, respectively.

For the individual's profile of CK concentration of elite soccer players, the frequency higher than the expected of $\% \Delta \mathrm{CK}_{\text {Game }}$ was observed in the $2^{\text {nd }}$ quartile while the frequency in the $1^{\text {st }}$ and $4^{\text {th }}$ was lower than the expected one. However, no difference was found between the observed frequency and the expected one in the $3^{\text {rd }}$ quartile (table 1).

Table 1. Observed and expected frequencies in each quartile of $\% \Delta \mathrm{CK}_{\text {Game }}$ from 17 soccer player.

\begin{tabular}{c|c|c}
\hline Quartile & N Observed & N Expected \\
\hline $1^{\circ}$ Quartile & $26(14.2 \%)^{*}$ & 45.8 \\
\hline $2^{\circ}$ Quartile & $71(38.8 \%)^{*}$ & 45.8 \\
\hline $3^{\circ}$ Quartile & $46(25.1 \%)$ & 45.8 \\
\hline $4^{\circ}$ Quartile & $40(21.9 \%)^{*}$ & 45.8 \\
\hline Total analyses & 183 & 183 \\
\hline
\end{tabular}

Value of chi-square 22.21. * Observed frequency different to the expected $(p<0.01)$.
The comparison of CK concentration between the periods was performed, made with the data of 12 soccer players. Two soccer players were excluded because of injury and for having remained inactive for more than 20 consecutive days. In addition, three others were excluded for not having at least one CK concentration analysis in each period. In the three analyzed periods during the competition, it was observed that the highest $\% \triangle \mathrm{CK}_{\text {Game }}$ of the intermediate and final periods was lower than the highest $\% \triangle \mathrm{CK}_{\text {Game }}$ of the initial period (figure 1). Moreover, it was observed that all soccer players reached the $\mathrm{CK}_{\text {Max }}$ between the $1^{\text {st }}-13^{\text {th }}$ games (value of median in the $5^{\text {th }}$ game). During the competition, there were four soccer players who sustained muscle injury. Among them, two soccer players had the post-injury $\mathrm{CK}_{\text {Game }}$ measured as 577 and above $2000 \mathrm{U} / \mathrm{L}$ (value above the detectable by the instrument), well above their respective $\mathrm{CK}_{\text {Max }}$ of 558 e $573 \mathrm{U} / \mathrm{L}$. Using these measures between periods CK concentration, the standard error of measurement according to Weir ${ }^{24}$ was $31.1 \%$.

$\mathrm{CK}_{\text {Game }}$ was higher than $\mathrm{CK}_{\text {Bas }}(\mathrm{p}<0.001)$ and the $\mathrm{CK}_{\text {Game }}$ showed a non-normal distribution, with values ranging from 141 to $1830 \mathrm{U} / \mathrm{L}$ (figure 2). The median of $\mathrm{CK}_{\mathrm{Bas}} \mathrm{CK}_{\mathrm{Max}} \Delta \mathrm{CK}_{\mathrm{Max}} \mathrm{CK}_{\text {Game' }}$ and $\triangle \% \mathrm{CK}_{\text {Game }}$ was $120 \mathrm{U} / \mathrm{L}$ (range 26.3-475 U/L), $626 \mathrm{U} / \mathrm{L}$ (range 350-1830 U/L), $478 \mathrm{U} / \mathrm{L}$ (range 251.8-1355 U/L), $376.5 \mathrm{U} / \mathrm{L}$ (range 141-1830 U/L) and 47.30\% (range 6.6-100.0\%) respectively. During the competition, the soccer players had their CK concentration measured 10.8 times on the average.

Moreover, the monitoring of training volume, training intensity and their correlations with $\% \Delta \mathrm{CK}_{\text {Game }}$ are in the table 2. During the all season, their mean playing official soccer match was $1505.9 \pm 571.4 \mathrm{~min}$. The mean values for temperature and air relative humidity during the study were $20.9 \pm 4.6^{\circ} \mathrm{C}$ e $69.0 \pm 0.2 \%$, respectively.

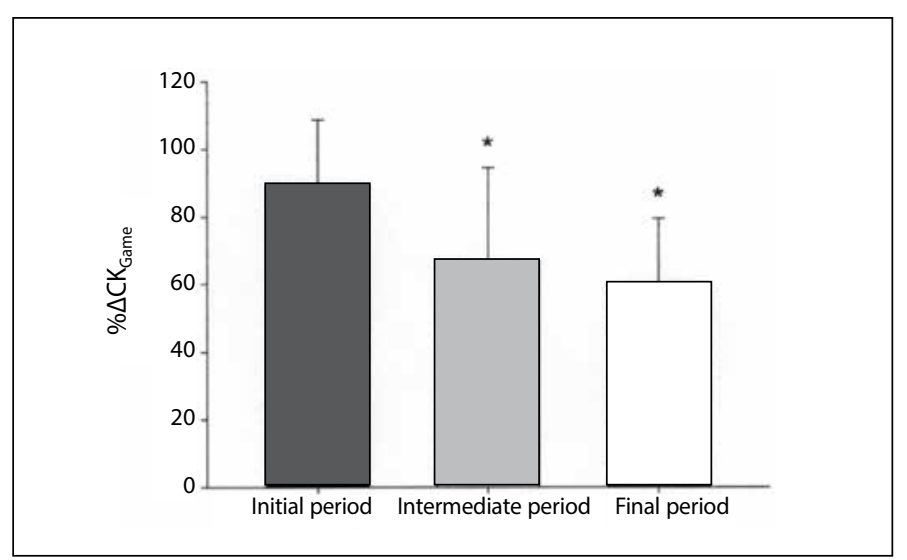

Figure 1. Highest $\% \triangle C K G a m e$ in each period. $N=12$. Significative difference in comparison to Initial Period. $(p<0.05)$.

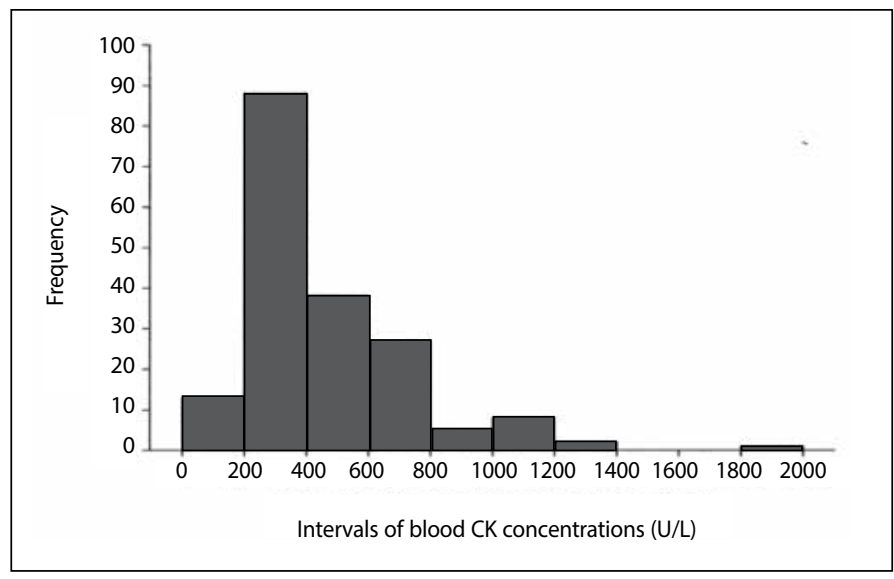

Figure 2. Frequencies of observations of CKGame of 17 soccer players during a Brazilian championship. 
Table 2. Description of training volume and training intensity and their correlations with \% $\triangle \mathrm{CK}_{\mathrm{Gam}}$

\begin{tabular}{c|c|c|c|c}
\hline & $\begin{array}{c}\text { Initial period } \\
(\text { mean } \pm \text { SD) }\end{array}$ & $\begin{array}{c}\text { Intermediate } \\
\text { Period (mean } \pm \text { SD) }\end{array}$ & $\begin{array}{c}\text { Final period } \\
(\text { mean } \pm \text { SD) }\end{array}$ & $\begin{array}{c}\text { Correlations } \\
\text { with } \% \Delta \mathbf{C K}_{\text {Game }}\end{array}$ \\
\hline $\begin{array}{c}\text { Training } \\
\text { volume } \\
(\text { min) }\end{array}$ & $4710.3 \pm 1340.2$ & $1636.6 \pm 461.3$ & $4240.0 \pm 974.6$ & $\begin{array}{r}r=0.346, \\
r^{2}=12 \%, \\
p=0.039\end{array}$ \\
\hline $\begin{array}{c}\text { Training } \\
\text { intensity } \\
\left(\% \mathrm{HR}_{\text {Max }}\right)\end{array}$ & $71.3 \pm 4.3$ & $71.1 \pm 7.4$ & $74.0 \pm 3.8$ & $\begin{array}{r}r=-0.006, \\
r^{2}=0.004 \%, \\
p=0.971\end{array}$ \\
\hline
\end{tabular}

\section{DISCUSSION}

To the best of our knowledge, this is the first report to determine the individual's profile of blood CK concentration of elite soccer players therewith, the main finding of this study was the identification of the individual's profile during competition in the $2^{\text {nd }}$ quartile. Thus, the frequency of $\% \Delta C K_{\text {Game }}$ at the $2^{\text {nd }}$ quartile was higher than expected. On the other hand, the observed frequency at the $1^{\text {st }}$ and $4^{\text {th }}$ quartiles was lower than expected. Thus, based on the CK concentration response, the soccer players presented muscle damage between 25 and $50 \%$ of the percentage relation between $\Delta \mathrm{CK}_{\text {Game }}$ and $\Delta C K_{\text {Max }}$ along the competition, suggesting that it did not represent an elevated magnitude of muscle damage. However, they did not have a low magnitude of muscle damage and according to the frequencies during the $1^{\text {st }}$ quartile, were lower than expected. Moreover, there was a decrease of the highest frequency of $\% \Delta \mathrm{CK}_{\text {Game }}$ of each soccer player, in the intermediate and final periods in comparison with the initial period. Considering that in the present study, there was not a monitoring only of intensity of games, the chronic effect of training and games in CK concentration response was also observed, and thus the CK concentration observed decrease suggests that the soccer players had muscle adaptations owing to the stimuli inflicted during the season ${ }^{25}$. Such a fact contributed to the higher observed frequency of $\% \Delta C K_{\text {Game }}$ at the $2^{\text {nd }}$ quartile and lower at the $4^{\text {th }}$ quartile. The profile of the observed $\% \Delta \mathrm{CK}_{\mathrm{Game}}$ corresponded to that of a sample of soccer players of a team that ranked among the top four teams in the championship.

The reduction of CK concentration observed over time in this study may be ascribed to muscle adaptation ${ }^{26}$, which has been observed in protocols of eccentric exercise ${ }^{27}$ and in soccer players during a Brazilian first-division championship ${ }^{10}$. One of the mechanisms responsible for muscle adaptation can be derived from the activation of myogenic satellite cells that act in the repair of damaged muscle fibers ${ }^{28}$. According to $\mathrm{CK}_{\operatorname{Max}}$ observed in the initial period, the first games of each soccer player may represent more muscle damage than the other games. Therefore, it may contribute for the $\mathrm{CK}_{\max }$ that was found in the soccer players in the first games.

Different results were reported by Zoppi et al. ${ }^{9}$ who did not see any decreases of $\mathrm{CK}$ concentration for five months of the soccer championship, but they performed their study during a regional competition with a different competitive calendar and the players belonged to a different competitive level than in the present study. Silva et al. ${ }^{12}$, who evaluated the CK concentration response during a three-month training period, did not report any differences during that period. However, they performed only three evaluations, one being at the beginning, another 6 weeks later and the last on the $12^{\text {th }}$ week, each evaluation being performed 12 hours after the last activity. The studies that analyzed the CK concentration during a soccer season evaluated it once a month ${ }^{9,10}$ or once every six weeks ${ }^{12}$ and they did not take into consideration whether the last physical activity before each evaluation had been a game or a training session?,10,12.
Therefore, the present study was the first, to our knowledge, that evaluated the CK concentration after official games and which had an elevated number of measurements on the same individual. The protocol we used, measuring CK concentration after every game appears to be more adequate to detect alterations in that marker than the protocol used in previous studies.

Throughout the competition the CK concentration of the soccer players remained above the resting and reference values accept for the sedentary population. This corroborates the results of other studies with soccer players during a competition ${ }^{9,10}$ and studies that analyzed the increase of CK concentration 48h after a single game 1,20,29. Moreover, the median blood $\mathrm{CK}_{\text {Game }}$ concentrations (i.e., $376.5 \mathrm{U} / \mathrm{L}$ which corresponded to a $\% \Delta \mathrm{CK}_{\text {Game }} 47.30 \%$ ) of the present study were similar to the mean values of plasmatic concentrations of studies with soccer players in competitions $5^{9,10}$ and slightly lower than studies that evaluated the players after a single soccer match $1,20,30$. One limitation of the present study was the one assessment of $\mathrm{CK}_{\mathrm{Bas}}$ however, the $\mathrm{CK}_{\text {Bas }}$ about the values of sedentary adult men ${ }^{21}$ and soccer players in rest remained'.

At the end of the competition, the soccer players in the present study showed a $\mathrm{CK}_{\operatorname{Max}}$ of $626 \mathrm{U} / \mathrm{L}$. The $\mathrm{CK}$ concentration of 14 soccer players remained below the threshold value for the increased risk of injury suggested by Mougios ${ }^{13}(1492 \mathrm{U} / \mathrm{L})$ and Lazarim et al. ${ }^{10}$ (975 U/L). It should be noted that the CK concentration of three soccer players was above $975 \mathrm{U} / \mathrm{L}$ and the highest being above $1492 \mathrm{U} / \mathrm{L}$, but no clinical problems were reported. Lazarim et al. ${ }^{10}$, reported that in his study, one soccer player whose CK concentration exceeded the proposed reference value was injured. During the present study, four soccer players underwent muscle injury, with two of them presenting $\mathrm{CK}_{\text {Game }}$ above their $\mathrm{CK}_{\text {Max, }}$ This may suggest the occurrence of a higher rupture of the muscle tissues, resulting in a larger extravasation of CK into the blood stream ${ }^{31}$.

The observed positive correlation between training volume and $\% \triangle C K G a m e$ as well as the absence of correlation with training intensities indicates that training volume, likewise type of exercise ${ }^{21}$ might be, among others, one factor that influences the CK concentration?. However, only $12 \%$ of common variance exists between training volume and CK concentration. The remaining $88 \%$ is originated from others variables. Thus, CK concentration should be interpreted along with other variables such as training status and the individual response to $\% \Delta \mathrm{CK}_{\text {Game. }}$.

Due to the high variability found in $\mathrm{CK}$ concentration response to exercise in this as well as in other studies ${ }^{15,21}$, the $\mathrm{CK}_{\operatorname{Max}}$ of soccer players during a competition may not reach the proposed reference values, even knowing that the soccer players are being subjected to elevated muscle damage. Therefore, the use of a fixed CK threshold value may not be warranted. It is likely that different soccer players have different thresholds and the individualized CK concentration profile should be used to monitor each soccer player during a championship.

\section{CONCLUSIONS}

The individualized CK concentration responses of the elite soccer players during a Brazilian championship in the present study indicate that they did not remain at elevated muscle damage. One probable muscle adaptation may occur based on reduced CK concentration.

All authors have declared there is not any potential conflict of interests concerning this article. 


\section{REFERENCES}

1. Ispirlidis I, Fatouros IG, Jamurtas AZ, Nikolaidis MG, Michailidis I, Douroudos I, et al. Time-course of changes in inflammatory and performance responses following a soccer game. Clin J Sport Med. 2008;18(5):423-31.

2. Dupont $G$, Nedelec M, McCall A, McCormack D, Berthoin S, Wisløff U. Effect of 2 soccer matches in a week on physical performance and injury rate. Am J Sports Med. 2010;38(9):1752-8.

3. Nedelec M, McCall A, Carling C, Legall F, Berthoin S, Dupont G. The influence of soccer playing actions on the recovery kinetics after a soccer match. J Strength Cond Res. 2014;28(6):1517-23.

4. Bangsbo J. The physiology of soccer--with special reference to intense intermittent exercise. Acta Physiol Scand Suppl. 1994;619:1-155

5. Stølen T, Chamari K, Castagna C, Wisløff U. Physiology of soccer: an update. Sports Med 2005;35(6):501-36.

6. Clarkson PM, Hubal MJ. Exercise-induced muscle damage in humans. Am J Phys Med Rehabil. 2002;81(Suppl 11):S52-69.

7. Brancaccio P, Maffulli N, Buonauro R, Limongelli FM. Serum enzyme monitoring in sports medicine Clin Sports Med. 2008;27(1):1-18.

8. Nosaka K, Clarkson PM. Variability in serum creatine kinase response after eccentric exercise of the elbow flexors. Int J Sports Med. 1996;17(2):120-7.

9. Zoppi CC, Antunes-Neto J, Catanho FO, Goulart LF, Motta e Moura N, Macedo DV. Alterações em biomarcadores de estresse oxidativo, defesa antioxidante e lesão muscular em jogadores de futebol durante uma temporada competitiva. Rev Paul Educ Fis. 2003;17:119-30

10. Lazarim FL, Antunes-Neto JM, da Silva FO, Nunes LA, Bassini-Cameron A, Cameron LC, et al. The upper values of plasma creatine kinase of professional soccer players during the Brazilian National Championship. J Sci Med Sport. 2009;12(1):85-90.

11. Smith LL. Cytokine hypothesis of overtraining: a physiological adaptation to excessive stress? Med Sci Sports Exerc. 2000;32(2):317-31.

12. Silva ASR, Santhiago V, Papoti M, Gobatto CA. Psychological, biochemical and physiological responses of brazilian soccer players during a training program. Sci Sports. 2008;23:66-72.

13. Mougios V. Reference intervals for serum creatine kinase in athletes. Br J Sports Med. 2007:41(10):674-8

14. Hammouda O, Chtourou H, Chaouachi A, Chahed H, Bellimem H, Chamari K, et al. Time-of-day effects on biochemical responses to soccer-specific endurance in elite Tunisian football players. J Sports Sci. 2013;31(9):963-71.

15. Totsuka M, Nakaji S, Suzuki K, Sugawara K, Sato K. Break point of serum creatine kinase release afte endurance exercise. J Appl Physiol (1985). 2002;93(4):1280-6.

16. Silva ASR, Papoti M, Pauli JR, Gobatto CA. Elaboração de tabelas de percentis através de parâmentros antropométricos, de desempenho, bioquímicos, hematológicos, hormonais e psicológicos em futebolistas profissionais. Rev Bras Med Esporte. 2012;18(3):148-152.
17. Brink MS, Nederhof E, Visscher C, Schmikli SL, Lemmink KA. Monitoring load, recovery, and performance in young elite soccer players. J Strength Cond Res. 2010;24(3):597-603.

18. Meeusen R, Duclos M, Foster C, Fry A, Gleeson M, Nieman D, et al. Prevention, diagnosis, and treatment of the overtraining syndrome: joint consensus statement of the European College of Sport Science and the American College of Sports Medicine. Med Sci Sports Exerc. 2013;45(1):186-205.

19. Jackson AS, Pollock ML. Generalized equations for predicting body density of men. Br J Nutr. 1978;40(3):497-504

20. Fatouros IG, Chatzinikolaou A, Douroudos II, Nikolaidis MG, Kyparos A, Margonis K, et al. Time-course of changes in oxidative stress and antioxidant status responses following a soccer game. J Strength Cond Res. 2010;24(12):3278-86.

21. Yamin C, Oliveira J, Meckel Y, Eynon N, Sagiv M, Ayalon M, et al. CK-MM gene polymorphism does not influence the blood CK activity levels after exhaustive eccentric exercise. Int J Sports Med. 2010;31(3):213-7.

22. Bangsbo J. Mizuno M. Morphological and metabolic alterations in soccer players with detraining and retraining and their relation to performance. In: Reilly T, Lees A, Davids K, Murphy WJ, editors. Science and Football. Proceeding of the first world congress. Liverpool, England; 1987. p. 11-24.

23. Antonacci L, Mortimer LF, Rodrigues VM, Coelho DB, Soares DD, Silami-Garcia E. Competition, estimated, and test maximum heart rate. J Sports Med Phys Fitness. 2007;47(4):418-21.

24. Weir JP. Quantifying test-retest reliability using the intraclass correlation coefficient and the SEM. J Strength Cond Res. 2005;19(1):231-40.

25. Maio Alves JM, Rebelo AN, Abrantes C, Sampaio J. Short-term effects of complex and contrast training in soccer players' vertical jump, sprint, and agility abilities. J Strength Cond Res 2010;24(4):936-41

26. McHugh MP. Recent advances in the understanding of the repeated bout effect: the protective effect against muscle damage from a single bout of eccentric exercise. Scand J Med Sci Sports. 2003;13(2):88-97.

27. Chen TC, Nosaka K. Effects of number of eccentric muscle actions on first and second bouts of eccentric exercise of the elbow flexors. J Sci Med Sport. 2006;9(1-2):57-66.

28. Tidus PM. Skeletal muscle damage and repair. United Kingdom: Human Kinetics; 2008.

29. Ascensão A, Rebelo A, Oliveira E, Marques F, Pereira L, Magalhães J. Biochemical impact of a socce match - analysis of oxidative stress and muscle damage markers throughout recovery. Clin Biochem. 2008;41(10-11):841-51

30. Ascensão A, Leite M, Rebelo AN, Magalhäes S, Magalhäes J. Effects of cold water immersion on the recovery of physical performance and muscle damage following a one-off soccer match. J Sports Sci. 2011;29(3):217-25

31. Martínez-Amat A, Boulaiz H, Prados J, Marchal JA, Padial Puche P, Caba O, et al. Release of alpha-actin into serum after skeletal muscle damage. Br J Sports Med. 2005;39(11):830-4. 